\title{
Macrofossils associated with the fossil fern spore Cyatheacidites annulatus and their significance for Southern Hemisphere biogeography
}

\author{
R.S. Hill ${ }^{\mathrm{a}, *}$, M.K. Macphail ${ }^{\mathrm{b}}$, G.J. Jordan ${ }^{\mathrm{c}}$ \\ ${ }^{a}$ Centre for Evolutionary Biology and Biodiversity, Department of Environmental Biology, \\ University of Adelaide, SA 5005, Australia \\ ${ }^{\mathrm{b}}$ Archaeology \& Natural History, RSPAS, Australian National University, Canberra, ACT 0200, \\ Australia \\ ${ }^{\mathrm{c}}$ School of Plant Science, University of Tasmania, Tas 7001, Australia \\ *Corresponding author. Fax: +61 8 83036222. E-mail: bob.hill@ adelaide.edu.au
}

\begin{abstract}
Oligocene-Early Miocene macrofossils of parts of a fertile frond are assigned to the extant South American species Lophosoria quadripinnata (Gmel.)C.Chr. These macrofossils bear the dispersed spore species Cyatheacidites annulatus Cookson ex Potonié. This species has an extensive recorded history in the Southern Hemisphere, only recently retracting to its current range. This history suggests major episodes of expansion and extinction, with a double extinction occurring in Australia and Cenozoic introductions to the Kerguelen Islands and the Falkland Plateau that probably involved transoceanic dispersal. Cretaceous Lophosoria records may or may not include L. quadripinnata, but they probably included several species, especially in the southern South America-Antarctic Peninsula region, where other dispersed spore species of Cyatheacidites and the macrofossil species $L$. cupulatus are recognised. This species diversity probably collapsed during the Cretaceous, possibly due to angiosperm radiation. The Cenozoic record of C. annulatus in Australia appears to represent a radiation of L. quadripinnata, probably from South America.
\end{abstract}

Keywords: Lophosoria, biogeography, Southern Hemisphere, Cretaceous, Cenozoic

\section{Introduction}


Southern Hemisphere biogeography is complex, with patterns produced by long-distance dispersal overlaying relict patterns from the break-up of Gondwana. Many studies are based on the modern distribution of species, but recent palaeobotanical work has shown that extinctions have played a major part in the evolution of these patterns (e.g. Hill, 2001). In particular, many groups of plants had past distributions that could never be predicted based on modern species distributions (e.g. the cupressaceous genus Fitzroya Hook.f. ex Lindley in Tasmania (Hill and Whang, 1996).

A few key fossil taxa have provided important insights into the processes involved in Southern Hemisphere biogeography. Amongst plants, the angiosperm Nothofagus Blume has traditionally been seen as a key (Van Steenis, 1971; Hill, 2000), but the fossil fern spore species Cyatheacidites annulatus demonstrates some very different patterns. The distribution of these spores is important for two reasons; firstly it demonstrates at least a double extinction event, probably across a broad geographic range, and secondly it demonstrates the complexity of some biogeographic patterns in the Southern Hemisphere. Although C. annulatus spores occur widely in the Southern Hemisphere, there is little doubt that they are a direct record of the fern genus Lophosoria, which now occurs naturally only in South America (Erdtamn, 1957; Dettmann, 1986; Fig. 1). However, the fossil record suggests a greater diversity for Lophosoria in the past compared with the single living species for three reasons:

1. There are other fossil species of Cyatheacidites besides $C$. annulatus that may also be related to Lophosoria. Dettmann (1986) recognised two other Cretaceous species of Cyatheacidites, C. archangelskyi and C. botuliformis. She suggested an affiliation of all Cyatheacidites species with Lophosoria.

2. Cyatheacidites annulatus spores encompass a broader range of morphologies than the single extant species Lophosoria quadripinnata (Dettmann, 1986; Kurmann and Taylor, 1987), although both taxa share diagnostic characters such as a broadly rounded cingulum and contact area pads on the proximal contact faces with a raised foveolate pad (Plate I e,f). Dettmann (1986) merged C. tectifera into C. annulatus, whereas Kurmann and Taylor (1987) considered them as distinct taxa, noting that the major difference is that the former species is somewhat smaller. 
3. The single macrofossil record of fronds bearing $C$. annulatus spores was not assigned to $L$. quadripinnata, but to a new fossil species L. cupulatus (Cantrill, 1998). This record, from the Aptian of Snow Island in the Antarctic Peninsula, has a long time separation from the extant species. The only other macrofossil record of Lophosoria is sterile pinnules from the Tertiary of King George Island, Antarctic Peninsula, described as Lophosoria antarctica (Torres and Méon, 1993). In the absence of attached sporangia and spores these are not a convincing record of the genus. Nishida (1982) described a petrified rachis from the Aptian of Japan as Lophosoriorhachis japonica and suggested that it shares some anatomical features with Lophosoria. Dettmann (1986) questioned the congeneric status of this fossil with Lophosoria because the stem characters of Lophosoria are not entirely definitive and the associated fossil spore genus Lophosoria is unknown in Japan.

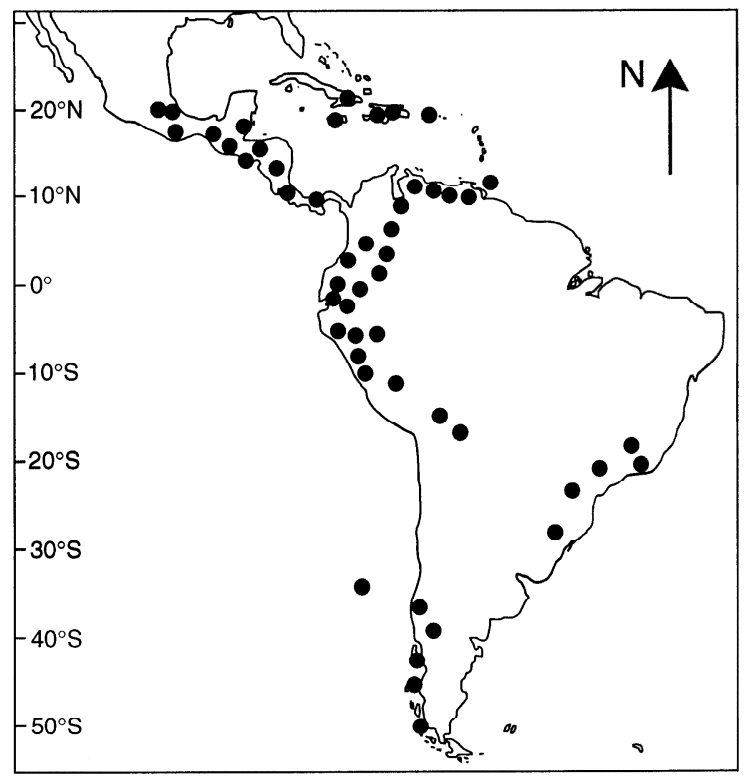

Figure 1. Map of South America showing the current distribution of Lophosoria quadripinnata (modified from Tryon and Tryon, 1982). 


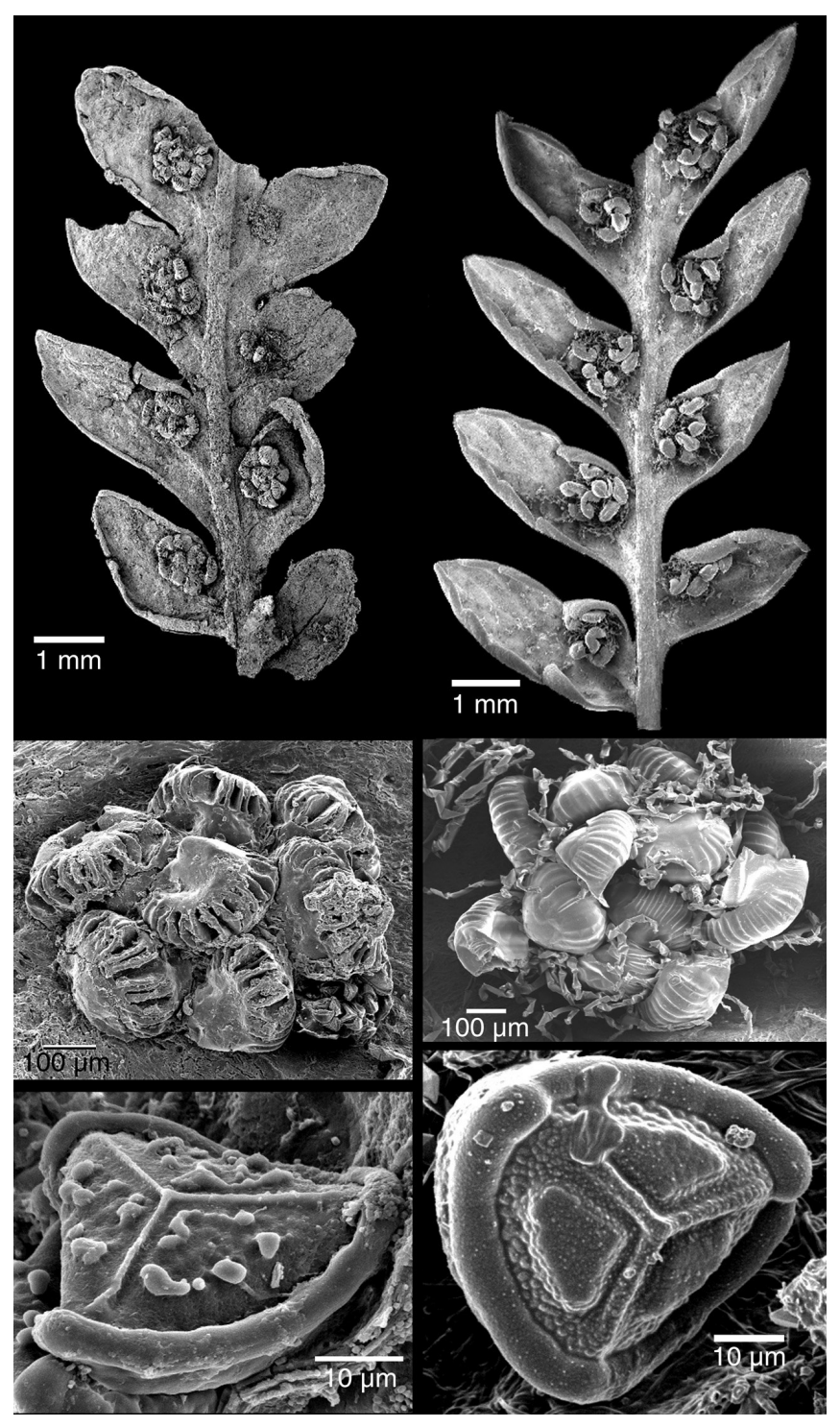

Plate I. a. Part of a frond of Lophosoria quadripinnata from the Late Oligocene-Early Miocene sediments at Balfour. Note the sori present. b. Part of a frond of extant L. quadripinnata from South America. c,d. A single sorus of fossil (c) and living (d) L. quadripinnata. e,f. Spores from fossil (e) and living (f) L. quadripinnata.

Therefore, the discovery of macrofossils bearing Cyatheacidites annulatus spores in Oligocene-Early Miocene sediments at Balfour, north-west Tasmania is particularly significant. Although they are remote both in space and time from the extant populations of Lophosoria quadripinnata, they provide firm evidence for the conspecificity of at least some $C$. annulatus spores with extant L. quadripinnata. This is important because it means that not not only does the 
extant genus have a significant fossil record, but also the extant species can be shown to have a long and spatially complex history.

\section{Material and Methods}

The Balfour sediments occur in north-west Tasmania near Mt Balfour (41 ${ }^{\circ} 18^{\prime} \mathrm{S}, 144^{\circ} 54^{\prime} \mathrm{E}$, $240 \mathrm{~m}$ asl, fig. 2). The sediments were partially exposed in a road-cutting, and were collected during two trips in late 1998. Plant macrofossils occur sporadically throughout the sediment, and preservation is variable. Some of the sediment can be disaggregated and the fossils removed intact. This was achieved by soaking blocks of sediment in absolute alcohol and treating them for several hours in an ultrasonic bath. The resultant slurry was sieved and the remaining organic material and coarse sediment was sorted under a low power dissecting microscope. Three specimens of fertile fern pinnules that can be assigned to Lophosoria were recovered from the sediment and were cleaned in 50\% hydrofluoric acid overnight, and rinsed in water several times.

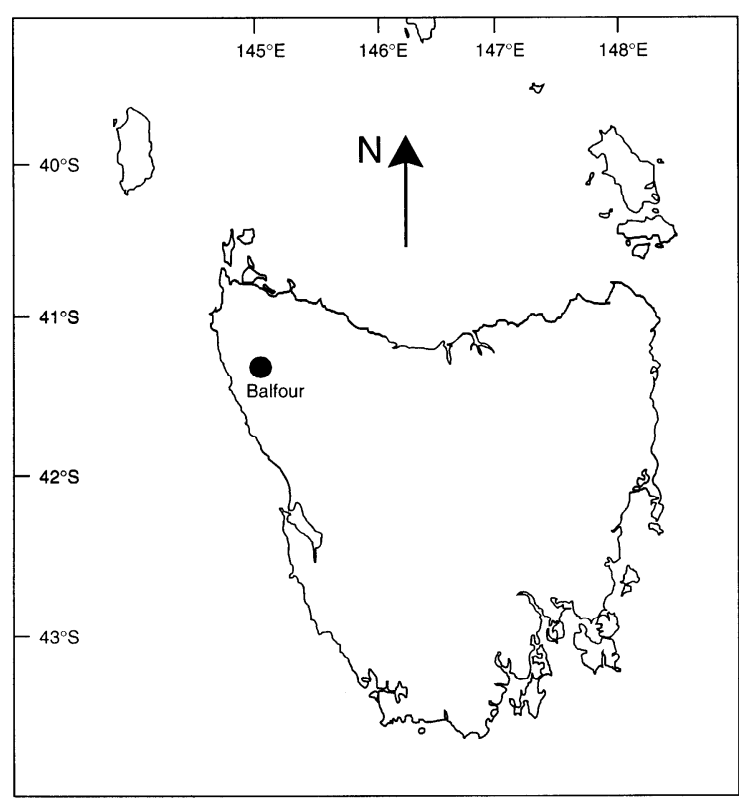

Figure 2. Map of Tasmania showing the location of the Balfour site. 
The specimens were then attached to aluminium stubs with double-sided adhesive and coated with a gold-carbon mix. They were then examined using a Philips XL20 scanning electron microscope operated at $10 \mathrm{kV}$. Each specimen contains intact sori (Plate Ia,c), and some of the sporangia contain many spore tetrads, suggesting that the specimens may not have been fully mature when detached from the parent plant and fossilised. Living specimens of Lophosoria quadripinnata were obtained from the Herbarium at the Royal Botanic Gardens, Sydney. These specimens were prepared for scanning electron microscopy in the same way as the fossil specimens.

The Balfour sediments are assigned to the Oligocene-late Early Miocene Proteacidites tuberculatus Zone using presence/absence and relative abundance criteria derived from the Gippsland and Bass Basins in Bass Strait (Stover and Partridge, 1973; A.D. Partridge \& M.K. Macphail, unpubl. data) and epicontinental Murray Basin in south-east Australia (Macphail and Truswell, 1989; Macphail, 1999).

The maximum age is Early Oligocene, based on the presence (spores and macrofossils) of the Proteacidites tuberculatus Zone index species Cyatheacidites annulatus. The minimum age is much less certain. It is probably no younger than late Early Miocene but could be as young as Middle Miocene.

The preferred upper age limit assumes that the presence of Rugulatisporites cowrensis (nearest living equivalent Calochlaena) is anomalous (early) for palaeoecological reasons. For example the assemblage includes an unusually high relative abundance (1\%) of Bluffopollis scabratus (nearest living equivalent Strasburgeria). A.D. Partridge (pers. comm.) has recorded B. scabratus in and through the $C$. bellus Zone in the Gippsland Basin, raising the possibility that the minimum age is Middle Miocene.

Whether the absence of other species used to define the base of the $C$. bellus Zone in the Gippsland, Bass and Murray Basins is significant is uncertain given that Bluffopollis scabratus is not alone in having a time distribution that varies latitudinally and longitudinally within southeastern Australia (see Macphail et al., 1994). For example, Canthiumidites bellus (nearest living equivalent Randia s.1.) has not yet been recorded in Tasmania. The earliest (questionable) record of Acaciapollenites myriosporites (nearest living equivalent Acacia) is in a Late Oligocene-Early Miocene microfloras at Monpeelyata on the Central Plateau. Symplocoipollenites austellus 
(nearest living equivalent Symplocos) has only been found in Plio-Pleistocene microfloras in western Tasmania.

Dominance of the microflora by evergreen rainforest gymnosperms (chiefly Dacrydium, Lagarostrobos and Podocarpus-Prumnopitys) and Nothofagus (subgenus Brassospora) points to uniformly humid, microtherm to lower mesotherm conditions. Similar conditions appear to have prevailed since the earliest Oligocene in western Tasmania (see Macphail and Hill, 1994) and are unhelpful in refining the age of the Balfour sample.

Accordingly it is unlikely that the age of the Balfour sample can be more precisely constrained until a local palynostratigraphy covering Cenozoic time is developed for Tasmania.

Independently dated cores from recently drilled ODP sites off the West Coast of Tasmania and on the South Tasman Rise and East Tasmanian Plateau offer the best opportunity so far to develop such a zonation.

\section{Results}

Fronds of extant Lophosoria quadripinnata are 2-pinnate-pinnatifid to 3-pinnate-pinnatisect, the segments are densely to very sparsely pubescent beneath and are often glaucous. The veins are free. The sori are abaxial, round, and borne singly on the fertile veins. The receptacle is scarcely elevated, and is paraphysate and exindusiate (Plate Ib,d) (Tryon and Tryon, 1982). The fossils match this description in all aspects that can be observed, except that it is not clear whether the sori bore paraphyses (hairs or hair-like structures in the sorus). However, these are highly variable in density in the living species, and may have been abraded from the fossils. There is evidence of poorly preserved bases for hairs on the frond surface away from the sori, but hairs are not preserved. The sporangia in the fossil are about $240 \mu \mathrm{m}$ in diameter, which is in the middle of the range measured for the extant species. Kramer (1990) illustrates approximately 32 cells for the annulus in L. quadripinnata, and in the scanning electron micrographs about half that number can be seen in the living specimen and in the fossil (Plate Ic,d). The number of spores per sporangium is 64 in L. quadripinnata. It was not possible to get a complete count in the fossil, but in on ruptured sporangium five separate tetrads of spores are visible (Plate Ic) in less than half of the sporangium, making 64 a very probable total number of spores. Therefore, since the fossil 
matched on all characters available, we conclude that they are conspecific with extant $L$. quadripinnata.

Spores isolated from the fossil specimens (Plate Ie) are consistent with the fossil species Cyatheacidites annulatus and to immature spores of the extant species Lophosoria quadripinnata (Plate If), since they bear the characteristic cingulum, and contact area pads on the proximal contact faces with a raised foveolate pad. There is variation in the degree of development of the contact area pads, but both fall within the range of L. quadripinnata and C. annulatus. The fossil spores have reduced development of the contact area pads (Plate Ie cf. If). However, the spores are still in tetrads in the sporangia, suggesting they are immature, and in immature $L$. quadripinnata the contact area pads are less well developed than in mature spores (Dettmann, 1986). Thus, although the Aptian specimens described as Lophosoria cupulatus (Cantrill 1998) differ morphologically from the extant L. quadripinnata, this Tasmanian evidence supports the hypothesis that at least some of the Cainozoic occurrences of $C$. annulatus represent the living species L. quadripinnata, which is therefore at least 20 million years old.

\section{Discussion}

Dispersed spores assigned to Cyatheacidites annulatus are spatially and temporally widespread in the Southern Hemisphere (Dettmann 1986). They first appear on the Antarctic Peninsula in the earliest Cretaceous and significantly later in the Cretaceous in South America and the Falkland Plateau and later again in Australia and New Zealand (Fig. 3). While the record on the Antarctic Peninsula is more or less continuous until the late Cretaceous, in South America, the Falkland Plateau and Australia the Cretaceous occurrence is followed by a long hiatus and a reappearance during the Cenozoic (Fig. 3). There is also a single problematic Cretaceous record from Africa, which may have been spatially and temporally close to occurrences on the Falkland Plateau. In New Zealand the Cretaceous record is relatively long (Fig. 3), but after its extinction it never reappears. The spores are known from the Kerguelen Islands only in the Miocene. Outside of South America, the last recorded appearance of $C$. annulatus is during the Pliocene in southern Australia. 


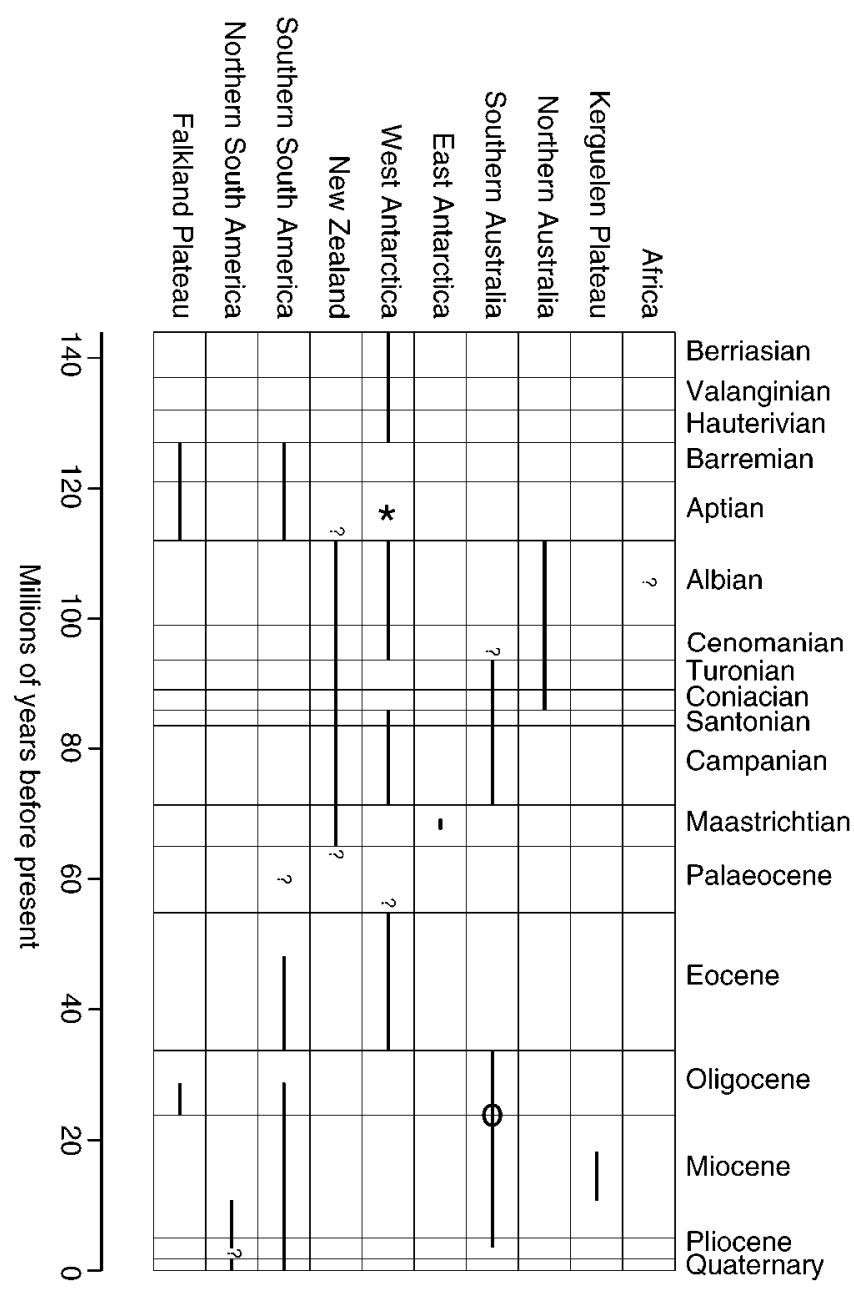

Figure 3. Stratigraphic range chart for the dispersed spore Cyatheacidites annulatus. $*=$ macrofossil record of Lophosoria cupulatus, o = macrofossil record of L. quadripinnata. Modified from Dettmann (1986), with additional data for New Zealand. 1. This record is unconfirmed (see Dettmann, 1986). 2.

Cookson (1947). 3. Helby et al. (1987). 4. Stover and Partridge (1973). 5. Macphail (1999). 6. No confirmed record. Absent in Turonian-Coniacian and Late Eocene sediments in Prydz Bay, East Antarctica (E.M. Truswell and M.K. Macphail pers. comm.). 7. Askin (1983). 8. I. Raine and D.Mildenhall (pers. comm.). 9. Archangelsky et al. (1984). 10. The cingulum of Paleocene specimens (not illustrated) recorded by Archangelsky (1973) is narrower than that of Cyatheacidites annulatus (5$6.5 \mu \mathrm{m}$ vs 8-10 $\mu \mathrm{m})$. 11. Cookson and Cranwell (1967). 12. Torres and Méon (1993). 13. Barreda (1996). 14. Muller et al. (1987). 15. Bratzeva (1983).

This is a remarkable history, consisting of a major Cretaceous radiation and extinction, followed by a Cenozoic radiation into South America while it was still connected to the Antarctic 
Peninsula and into southern Australia as it was separating from Antarctica. However, the Cenozoic introductions into the Falkland Plateau and the Kerguelen Islands, which are of volcanic origin, and predominantly less than 40 million years old (Coffin et al., 1999), may have involved dispersal over significant ocean gaps. Subsequently, all except the South American populations disappeared.

Living Lophosoria quadripinnata is a large fern (but not a tree fern as sometimes reported), now restricted to South America, where it ranges over more than $70^{\circ}$ of latitude (Fig. 1) and occurs primarily in cloud forest in the tropics and in cool, wet regions further south. It grows in a variety of habitats and readily colonises disturbed sites such as road cuttings and landslips, and may persist in logged forest, in pastures and in burned areas (Tryon and Tryon, 1982). This is an ecology that suggests it should have been well adapted to survive and flourish in the rapidly changing environments of the Neogene. It is possible that the ecology of specimens that occurred away from South America was different and less suited to changing environments, but if that was the case it is unlikely that they would have dispersed to such remote localities and established widely there in the first place. The spatial and temporal variation in extinction of taxa that have survived across only a limited part of their former range is important in understanding extinction processes generally and also in understanding the way in which the varying biotas of high southern latitudes developed. The fossil pollen and spore record is often criticised because a great deal of interpretation is based on identifications made from only a small part of the whole organism. However, when preserved in situ in macro-remains like those reported here, they increase our confidence in the pollen and spore data.

The Cretaceous records of Lophosoria may or may not have included L. quadripinnata, but they almost certainly included several Lophosoria species, especially in southern South America and the Antarctic Peninsula where other dispersed spore species of Cyatheacidites and the macrofossil species L. cupulatus are recognised (Dettmann, 1986; Cantrill, 1998). This species diversity probably collapsed during the Cretaceous, possibly due to angiosperm radiation. While we have no direct evidence that L. quadripinnata was present during the Cretaceous, we know that at least one Lophosoria species survived into the Cenozoic in South America. If only one species survived then it was either L. quadripinnata, or it evolved into it. Lophosoria appears to 
have flourished during the rifting of Australia from Antarctica, possibly due to high disturbance regimes that still favour it today.

Therefore it is probable that the Cenozoic record of Cyatheacidites annulatus in Australia, and presumably other places, represents a radiation of one to a few species, including Lophosoria quadripinnata, probably from South America. The alternative, that the species involved lingered on in the gaps between the Cretaceous and Cenozoic in, for example, Australia, is severely weakened by the fact that the Tasmanian macrofossil species is L. quadripinnata. For this to be so then L. quadripinnata had to be present in the Cretaceous and it had to be the species that survived unchanged in both Australia and South America. This is an unlikely combination of events. Hence the macrofossil data support the hypothesis that there was a double extinction of Lophosoria in Australia at least. Furthermore, it is likely that this species crossed at least two major water gaps (to the Kerguelens and the Falkland Plateau) as part of the Cainozoic expansion, although it did not re-invade New Zealand.

The most recent extinctions of Lophosoria quadripinnata everywhere except South America may have been due to a decline in the frequency of disturbance in suitably wet and warm areas during the Miocene-Pliocene. The larger South American land mass, and the dynamic nature of the Andes mountain chain provided a wider range of possible refugia than the other Southern Hemisphere land masses.

\section{Acknowledgements}

Thanks to Ian Raine and Dallas Mildenhall for unpublished spore data from New Zealand. The Herbarium at the Royal Botanic Gardens, Sydney, provided specimens of extant Lophosoria quadripinnata. This research was funded by the Australian Research Council.

\section{References}

Archangelsky, S., 1973. Palinologia del Paleoceno de Chubut. I. Descripciones sistematicas. Ameghiniana, 10: 339-399. 
Archangelsky, S., Baldoni, A., Gamerro, J.C. and Seiler, J., 1984. Palinologia estratigrafica del Cretacico de Argentina Austral. III Distribucion de las especies y conclusiones. Ameghiniana, 21: 15-33.

Askin, R.A., 1983. Tithonian (uppermost Jurassic)-Barremian (Lower Cretaceous) spores, pollen and microplankton from the South Shetland Islands, Antarctica. In: R.P. Oliver, P.R. James and J. Jago (Editors), Proceedings Ivth International Symposium on Antarctic Earth Science. Adelaide, pp. 295-297.

Barreda, V.D., 1996. Bioestratigrafia de polen y esporas de la Formacion Chenque, Oligocene Tardio? - Mioceno de las Provincas de Chubut y Santa Cruz, Patagonia, Argentina. Ameghiniana, 33: 35-56.

Bratzeva, G.M., 1983. Spores and pollenfrom Cenozoic sediments of the Falkland Plateau, Site 511. Initial Reports of the Deep Sea Drilling Project, 71: 907-932.

Cantrill, D.J., 1998. Early Cretaceous fern foliage from President Head, Snow Island, Antarctica. Alcheringa 22: 241-258.

Coffin, M., Frey, F. and Wallace, P., 1999. Ocean Drilling Program Leg 183 Preliminary Report Kerguelen Plateau-Broken Ridge: A large igneous province. http://wwwodp.tamu.edu/publications.

Cookson, I.C., 1947. Plant microfossils from the lignites of the Kerguelen Archipelago. B.A.N.Z. Antarctic Research Expedition 1929-1931 Reports, A2: 127-142.

Cookson, I.C. and Cranwell, L.M., 1967. Lower Tertiary microplankton, spores and pollen grains from southernmost Chile. Micropaleontology, 13: 204-216.

Dettmann, M.E., 1986. Significance of the Cretaceous-Tertiary spore genus Cyatheacidites in tracing the origin and migration of Lophosoria (Filicopsida). Spec. Pap. Palaeont. 35: 63-94.

Helby, R., Morgan, R. and Partridge, A.D., 1987. A palynological zonation of the Australian Mesozoic. Association of Australasian Palaeontologists Memoir, 4: 1-94.

Hill, R.S., 2000. Biogeography, evolution and palaeoecology of Nothofagus (Nothofagaceae): the contribution of the fossil record. Australian Journal of Botany, in press.

Hill, R.S. and Whang, S.S., 1996. A new species of Fitzroya (Cupressaceae) from Oligocene sediments in north-western Tasmania. Australian Systematic Botany 9: 867-875. 
Macphail, M.K., 1999. Palynostratigraphy of the Murray Basin, inland southeastern Australia. Palynology 23: 197-240.

Macphail, M.K., Alley, N.F., Truswell, E.M. and Sluiter, I.R., 1994. Early Tertiary vegetation. In: R.S. Hill (Editor), History of the Australian Vegetation: Cretaceous to Recent. Cambridge University Press, Cambridge, pp. 189-261.

Macphail, M.K. and Hill, R.S., 1994. K-Ar dated palynofloras in Tasmania 1: Early Oligocene, Proteacidites tuberculatus Zone sediments, Wilmot Dam, northwestern Tasmania. Papers and Proceedings of the Royal Society of Tasmania, 128: 1-15.

Macphail, M.K. \& Truswell, E.M. 1989. Palynostratigraphy of the central west Murray Basin. BMR Journal of Australian Geology \& Geophysics 11, 301-33.

Muller, J., de Di Giacomo, E. \& van Erve, A.W. 1987. A palynological zonationfor the Cretaceous, Tertiary and Quaternary of northern South America. AASP Contributions Series 19, 1-76.

Van Steenis C.G.G.J., 1971. Nothofagus, key genus of plant geography, in time and space, living and fossil, ecology and phylogeny. Blumea, 19: 65-98.

Stover, L.E. \& Partridge, A.D. 1973. Tertiary and Late Cretaceous spores and pollen from the Gippsland Basin, southeastern Australia. Proceedings of the Royal Society of Victoria 85, 237286.

Torres, T.G. and Méon, H. 1993. Lophosoria from the Tertiary of King George Island and central Chile: origin and dispersion in the southern hemisphere. Instit. Antartico Chileno Serie Cien., 43: $18-30$.

Tryon, R.M. and Tryon, A.F. 1982. Ferns and Allied Plants, Springer-Verlag, New York. 